\title{
Collaborative Modelling for Informed Decision Making and Inclusive Water Development
}

\author{
Laura Basco-Carrera ${ }^{1,2,3,4}$ - Eelco van Beek ${ }^{1,3}$. \\ Andreja Jonoski ${ }^{2}$ - Camilo Benítez-Ávila ${ }^{3}$. \\ FX PJ Guntoro 5
}

Received: 11 July 2016 / Accepted: 26 March 2017 /

Published online: 28 April 2017

(C) The Author(s) 2017. This article is an open access publication

\begin{abstract}
Ensuring availability and adequate management of water and sanitation for all is one of the key priorities for sustainable development. Integrated Water Resources Management is widely considered to be the best management process for securing water for all. However, implementing it remains a challenge for many decision makers and practitioners. In this article, we demonstrate an application of collaborative modelling to enhance and inform decisions and ensure an inclusive process. This collaborative modelling approach was applied to a river basin master plan for Pemali Comal River Basin Territory in Indonesia. Based on surveys of its development and the stakeholders and decision makers, collaborative modelling and traditional planning approaches for
\end{abstract}

Laura Basco-Carrera

Laura.BascoCarrera@deltares.nl

Eelco van Beek

Eelco.vanBeek@ deltares.nl

Andreja Jonoski

a.jonoski@unesco-ihe.org

Camilo Benítez-Ávila

c.a.benitezavila@utwente.nl

FX PJ Guntoro

fx_guntoro@yahoo.co.id

1 Deltares, Boussinesqweg 1, P.O. Box 177, 2629 HVDelft, the Netherlands

2 UNESCO-IHE Institute for Water Education, Westvest 7, 2601 DADelft, the Netherlands

3 University of Twente, 7500 AE, Enschede, the Netherlands

4 Present address: Unit Inland Water Systems, Department of Water Resources and Delta Management, Deltares, Boussinesqweg 1, P.O. Box 177, 2629 Delft, HV, Netherlands

5 PT Virama Karya, J1 Durian Raya 70, Semarang, Central Java, Indonesia 
river basin planning were compared. The results of the evaluation demonstrate the benefits of collaborative modelling for structuring stakeholder participation in modelling processes, managing conflicts among competing water users and social learning.

Keywords Water security $\cdot$ River basin planning $\cdot$ Collaborative modelling $\cdot$ Stakeholder participation · Indonesia

\section{Introduction}

Water management is an important challenge that numerous countries must face in order to survive and improve their levels of economic development. Water is a key condition for generating rural livelihoods, growing food, producing energy, ensuring industrial and service sector growth, and guaranteeing the integrity of ecosystems and the goods and services they provide. However, the allocation of water resources can and likely will create disputes among water users. Moreover, population growth and its associated urban developments to accommodate it leads to increasing water demand and water pollution; major causes of the growing pressures on our water resources systems (UN-Water 2006).

Integrated Water Resources Management (IWRM) has been accepted worldwide as the best mechanism to deliver improved water management decisions. One of the central aims of IWRM is to promote increased coordination and integration across different water users and sectors as a means of achieving more holistic water management and improving water resource sustainability (GWP 2000; Muller and Lenton 2009). The Sustainable Development Goals (SDGs) consider implementing IWRM as one of the key targets to be achieved by 2030 (United Nations 2016). In practice this requires an analysis of the inter-connection between problems and a clear focus on the goals to be achieved (Biswas 2008; Serrat-Capdevila et al. 2011; Vennix 1999). Moreover, human well-being and socio-economic development cannot ensue by focusing only from within the 'water box'. It is crucial to understand that water is not the main factor; rather it is just one of the factors of interest (Medema et al. 2008). The concept of water security has emerged as an attempt to address these challenges (Van Beek and Arriens 2014).

Multiple definitions of the concept of water security exist (Cook and Bakker 2012; Grey and Sadoff 2007; GWP 2012; WEF Water Initiative 2010). In this article the definition of UNWater (2013) is used: water security is the capacity of a population to safeguard sustainable access to adequate quantities of acceptable quality water for sustaining livelihoods, human well-being, and socio-economic development for ensuring protection against water-borne pollution and water-related disasters; and for preserving ecosystems in a climate of peace and political stability. In an attempt to quantify water security, the Asian Development Bank (ADB), in partnership with Asia-Pacific Water Forum (APWF), developed the Asian Water Development Outlook (AWDO) (ADB 2013). This framework provides a better understanding of the complexities and dimensions of water resources problems (i.e. household, urban, economic and environmental water security, and resilience to water-related disasters). The framework supports policy and decision making processes in terms of opportunities for investment, governance and capacity development.

Indonesia has a national water security index of 2 according to AWDO (2013), as it scores low in the key dimensions of household and urban water security and in resilience to water-related disasters. Despite significantly increasing the percentage of 
its population with access to safe drinking water from $70 \%$ (1990) to $85 \%$ (2012), only $20 \%$ of households in rural areas presently have access to piped water. In urban settings, such access only increases to $36 \%$. Similarly, approximately half of the total population (54\%) have access to sanitation. In terms of water quality, only $34 \%$ of the water is treated in waste water treatment plants in urban settings (ADB 2015). On Java, water security is exacerbated by the high risk of floods and droughts (ADB 2016; Deltares 2012).

Indonesia's policy and decision making processes for achieving water security are broadly based on an IWRM approach. This commenced in 1974 with the national river management water law (11/1974) and the establishment and formulation of River Basin Territories and master plans during the 1990s. However, these plans tended to follow a project-oriented development approach. In 2004, the legislation was renewed with Law No. 7/2004 on water resources and related governmental regulations (Peraturan Pemerintah), with the intention to shift to a more comprehensive and sustainable management approach. The integrated river basin master plan for Pemali Comal River Basin Territory was developed under this law. The new law aimed to protect, manage, rationalize usage, reduce waste and supervise the community utilization of water resources to guarantee water supply, quality and conservation. In line with the IWRM approach, the water resources law also recognized data and information, and stakeholder participation as supportive components for sustainable planning and implementation of water resources management policy (ADB 2016; Sukardi et al. 2013). However, in 2015, the Indonesian Constitutional Court revoked the 2004 water resources law due to disagreements surrounding the maintenance of clean water access for the whole population. The previous water law of 1974 was reinstated until a new legislation is adopted.

This study presents a collaborative modelling approach used in the preparation of the operational integrated river basin master plan in Pemali Comal River Basin Territory. This approach facilitates integration of data and information with decision making using modelling tools with stakeholder participation and negotiation for river basin planning. The approach was design considering the context and conditions of Pemali Comal River Basin Territory, specific use of the modelling tools, information handling, stakeholder involvement, modelling and organizing team, and means (Basco-Carrera et al. 2016; Henriksen et al. 2009). Secondly, the article presents an evaluation of the impacts of using collaborative modelling for river basin planning in comparison with traditional water resources planning approaches. To address this second objective, the Pemali Comal River Basin Territory was divided into two areas. In one area the collaborative modelling approach was applied for river basin planning, while in the other traditional planning methods were used. Both methods were then compared using two semi-structured questionnaires (i.e. pre-evaluation and post-evaluation forms) distributed to 29 stakeholder representatives.

The next section outlines the methods used to address both objectives. It provides a description of the study area and a comprehensive overview of the design and application of the collaborative modelling approach used for the preparation of the integrated river basin master plan in Pemali Comal River Basin Territory. Finally, the article reflects on the outcomes of using collaborative modelling in comparison with traditional planning approaches and provides lessons learnt for future applications of collaborative modelling in water resources management and planning and decision making processes. 


\section{Methods}

\subsection{Study Area}

Indonesia has been divided into River Basin Territories, which are areas with hydrological, and in some cases political boundaries, comprising one or more hydrological catchments (Peraturan Pemerintah RI 38/2011 Tentang Sungai) (ADB 2016). Pemali Juana covers two River Basin Territories: Pemali Comal and Jratunseluna. This study case focuses on Pemali Comal River Basin Territory. Pemali Comal is classified as cross-provincial River Basin and it is located in Central Java. It covers an area of about $4900 \mathrm{~km}^{2}$ along the North Coast of Java and consists of 32 watersheds. The river discharge in Pemali Comal varies considerably from one river to the other. The lowest average annual discharge is found in the Waluh river $\left(1 \mathrm{~m}^{3} / \mathrm{s}\right)$, and the highest in the Comal river $\left(130 \mathrm{~m}^{3} / \mathrm{s}\right)$. Average rainfall in the area is relatively high at $1700-5000 \mathrm{~mm} / \mathrm{year}$ and there are considerable groundwater resources and springs in the region.

At administrative level, Pemali Comal is composed of 5 districts (Kabupaten) and 2 cities (Kota) (Fig. 1). Its population is approximately 6.5 million (BAPPENAS 2008), with Brebes and Pemalang the most densely populated districts. Agriculture is the major economic activity in the region. Around $50 \%$ of the area is used for highly productive food crops. Coastal areas are the preferred location for the construction of fish ponds, and the textile (e.g. batik) and ship-building industries (ADB 2016).

\subsection{Problem Context}

Pemali Comal River Basin Territory has moderate vulnerability towards water security. Water stress is the main issue (ADB 2016; Deltares 2012), regardless of its relatively high rainfall. Water pollution (mainly from the high disposal of pollutants into the river by households and industries) and sea water intrusion have also become considerable issues in the coastal area. Moreover, the over-abstraction of groundwater for drinking water supply has caused significant ground subsidence $(8-10 \mathrm{~cm} /$ year at the coast). As such, regional water supply authorities have been forced to use springs located upstream for supplying water to coastal areas. This directly affects the water available for irrigation, causing water stress during dry seasons. Conflicts between public water supply companies and farmer associations have arisen as a consequence of this policy and its impacts. The poor condition of secondary infrastructure, erosion and sedimentation (mainly caused by the mining industry) are other important issues in Pemali Comal. These have resulted in a considerable reduction of reservoir storage capacity and reduced flood protection (Wahyudi et al. 2012).

Limited knowledge about the water resources system and capacities aggravate this situation. Thus, conservation and land use, awareness, education, institutional and administrative settings are among the other related issues facing decision makers and stakeholders.

\subsection{Collaborative Modelling Approach}

The collaborative modelling approach was developed according to the complexity of the policy problem encountered in Pemali Comal, as well as project means (2 years duration, 450,000 Euros budget). Its high degree of knowledge uncertainty and levels of stakeholder disagreement meant that this case was considered to constitute an unstructured policy problem 


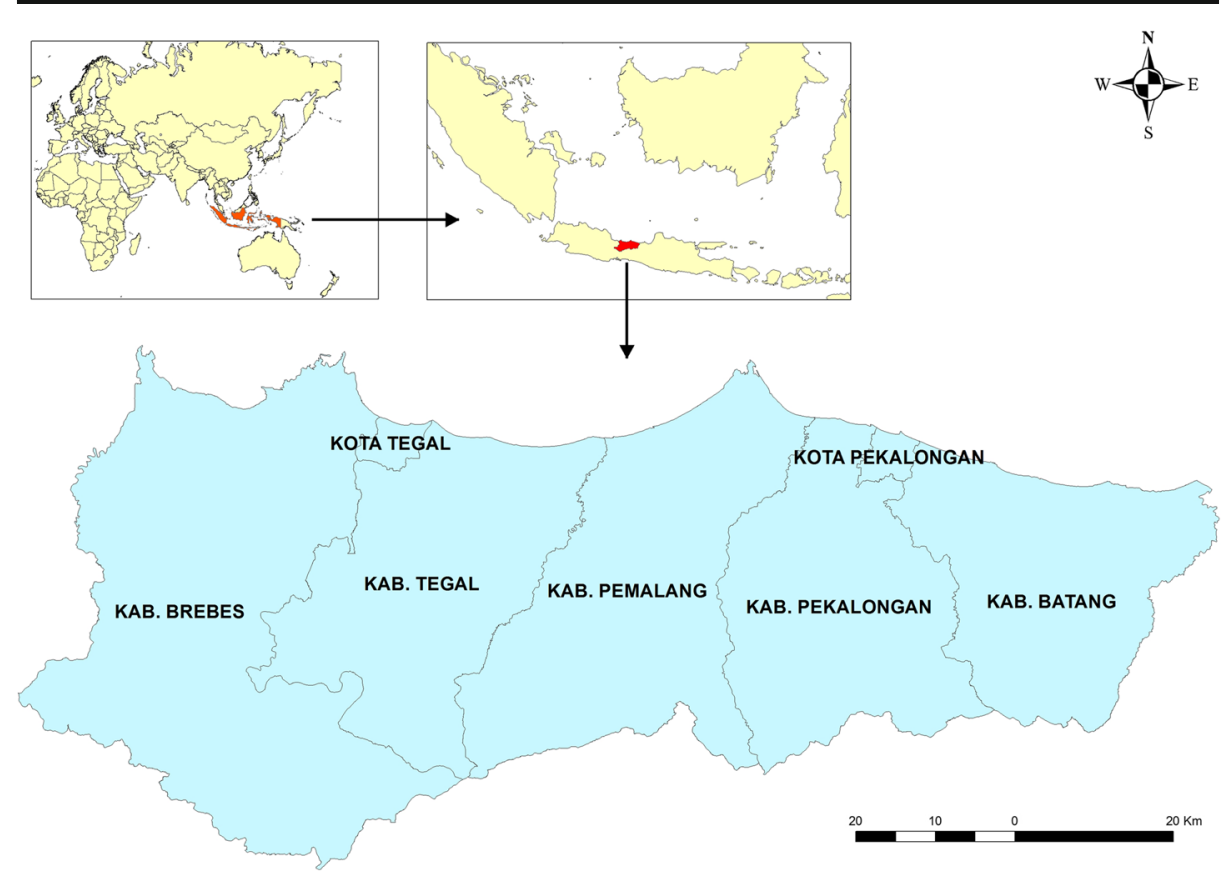

Fig. 1 The Pemali Comal River Basin Territory

(Graaf and Hoppe 1996; Hommes 2008; Hurlbert and Gupta 2015). The developed approach was thus conceived as an interactive and adaptive planning process in which stakeholder participation was complemented by the use of computer-based models and communication tools (Basco-Carrera et al. 2016). It included high levels of participation for key stakeholders and reduced participation for other interested stakeholders. A specific goal of the collaborative modelling approach was to enhance cooperation between the stakeholders (Sadoff and Grey 2005), as this is a critical factor for the implementability and sustainability of integrated river basin master plans. The planning and decision making process was treated as an adaptive process in which decision makers and involved stakeholders could determine the way to proceed depending upon the situation, goals and outputs obtained.

\subsubsection{River Basin Modelling Framework}

The river basin modelling framework used for the preparation of the master plan was adapted from the analytical framework used by Deltares for water resources studies (Loucks et al. 2005). It consists of an iterative step-by-step framework for informed planning and decision making by making use of data and modelling tools. The river basin modelling framework included certain additional steps relevant for Collaborative Modelling. The framework was composed of seven main planning stages: Initial analysis, Stakeholder analysis, Approach, Technical analysis, Customization, Preliminary analysis, and Detailed analysis (Fig. 2). During each planning stage, a model and/or tool was developed or used jointly with stakeholders.

A system dynamics model was constructed to identify and analyse the main water-related issues in Pemali Comal. The Group Model Building approach was used for its construction 


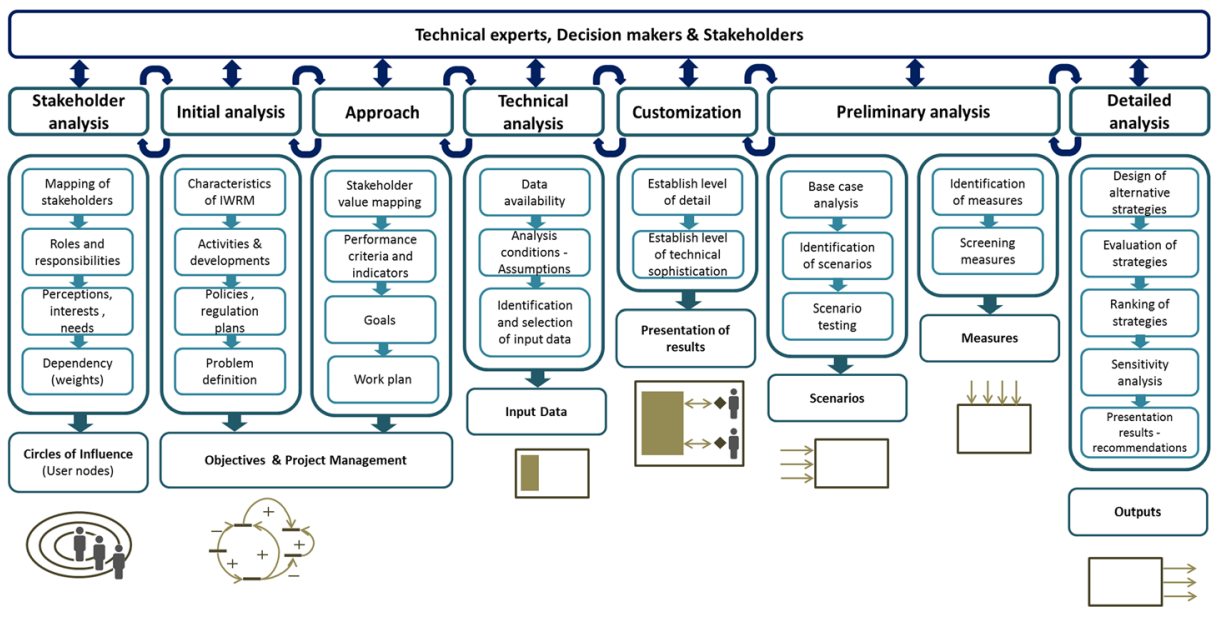

Fig. 2 River basin modelling framework

(Vennix 1999; Videira et al. 2017). The model aimed at creating a collective, integrated overview of the current and future problems in the territory. The water balance and water allocation analyses for Pemali Comal River Basin Territory were conducted using a RIver BAsin SIMulation (RIBASIM) model. Its design started during the technical analysis phase (Fig. 2). The construction of the model finalized with the selection of scenario conditions and potential measures during the preliminary analysis phase. The identification of potential measures was carried out together with stakeholders using the system dynamics model. The process followed an adapted mediated modelling approach (Van den Belt 2004). The RIBASIM model was then used for analysing the impacts of selected measures and their possible combinations, and supported the selection of the preferred strategy that was then included in the integrated river basin master plan (Fig. 2; detailed analysis).

\subsubsection{Participatory Engagement Structure}

The participatory engagement structure followed an adapted Circles of Influence approach (Fig. 3) (Bourget (2011); Cardwell et al. 2008) and was defined based on the results of a stakeholder analysis (Grimble and Chan 1995). It included four circles: (i) Circle A: model development team, (ii) Circle B: model users and validation team, (iii) Circle C: consultation and information team, and (iv) Circle D: decision makers. Stakeholder engagement comprised three levels of participation: co-construction, discussion and consultation (Arnstein 1969; Bruns 2003; Mostert 2003).

An organizing and modelling team supported by a regional team was involved throughout the planning process. Members supported the stakeholder consultation process for the development of both models: the conceptual model using system dynamics and RIBASIM.

The entire planning process was coordinated by a process manager responsible for (i) managing the stakeholder processes, (ii) guiding the organizing and modelling team, (iii) aiding in all negotiations, consensus building and decision making processes, and (iv) acting as a focal point between decision makers and the modelling team. 


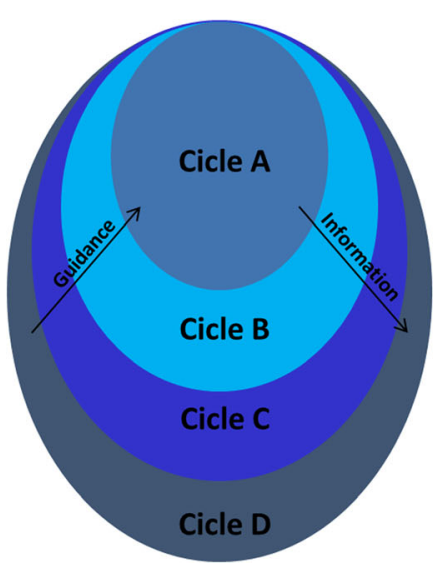

\begin{tabular}{|c|c|}
\hline Circle & Involved stakeholders \\
\hline A & $\begin{array}{l}\text { 1. Regional water resources management } \\
\text { implementation centre } \\
\text { 2. Public water supply authorities } \\
\text { 3. Provincial office of water resources } \\
\text { 4. Water users associations }\end{array}$ \\
\hline B & $\begin{array}{ll}\text { 1. } & \text { Circle A } \\
\text { 2. District water resources management authority } \\
\text { 3. Provincial spatial planning authority } \\
\text { 4. River basin water resources council }\end{array}$ \\
\hline $\mathrm{C}$ & $\begin{array}{l}\text { 1. Non-governmental Organizations } \\
\text { 2. Citizens organizations }\end{array}$ \\
\hline D & $\begin{array}{l}\text { 1. Governor } \\
\text { 2. Provincial water resources management authority } \\
\text { 3. Provincial administrative water resources council }\end{array}$ \\
\hline
\end{tabular}

Fig. 3 Circles of Influence approach

\subsubsection{Data and Simulation Model}

The analysis of the performance of the water resources system in Pemali Comal was undertaken using Deltares' RIBASIM modelling package (van der Krogt and Boccalon 2013). This simulated the hydrological cycle under various hydrological conditions whilst giving consideration to existing water users in the basin. Simulations established water allocations according to their prioritization, and thereby supported impact assessments of possible measures to each simulated scenario.

Hydrological water inputs comprised rainfall data from 2003 to 2014. Data was obtained from the Tropical Rainfall Measuring Mission (TRMM). For the schematization of Pemali Comal river basin, variable inflow nodes were used to represent the hydrological water inputs. Two major water users were considered in the analysis: public water supply and irrigation water demands. The model also included existing, planned and proposed storage facilities and other infrastructural measures (e.g. reservoirs, weirs, etc.).

An adaptive planning approach was followed during modelling analyses to achieve flexibility in the allocation of water over time (Jeuken et al. 2015; Speed et al. 2013). Four scenario conditions (all in relation to spatial planning) were considered to analyse future system performance: population growth, economic development, climate change and institutional setting. Population was assumed to grow by $1.5 \%$ in urban areas and a reduction of $0.5 \%$ in rural areas. A moderate economic growth scenario (4.5\%-6.5\%) based on the GDP was agreed. Two scenarios conditions were considered for computing the effects of climate change in rainfall: $\pm 3 \mathrm{~mm} /$ day (IPCC). Business as Usual and good governance were the two scenario conditions assumed for estimating the institutional setting in 2034. The good governance scenario assumed that decision makers and stakeholders would support integrated river basin master plan and follow its policies, and work jointly in the achievement of SDGs.

\subsection{Collaborative Modelling Process}

The collaborative modelling process was designed according to the river basin modelling framework. For the planning process Pemali Comal River Basin Territory was divided into two areas. In one area the collaborative modelling approach was applied (referred in this article as 
collaborative modelling area). In the other area, the traditional planning approach was followed (referred as conventional area). The collaborative modelling process comprised a public inception meeting, three collaborative modelling workshops and three public consultation events to discuss scope of the project, problem formulation, model design and construction, a set of rounds for model validation, water allocation and prioritization, model use for testing of measures and assessing their impacts, and finally the finalization of the plan. This process was combined with other participatory engagement methods: three consultation meetings and face-to-face interviews. In the conventional area, the stakeholder engagement process comprised a first meeting to present the project and three consultation meetings to present the results of the RIBASIM model, discuss possible measures and present the final integrated river basin master plan.

\subsubsection{Inception Phase}

The inception phase served to scope the project and collectively agree on specific goals and targets of the integrated river basin master plan. Collaborative modelling supported shared learning (Voinov and Bousquet 2010), consequently stakeholders understood that these could evolve over time and needed to be adaptive (Bousset et al. 2005; Medema et al. 2008; Mintzberg 1978). During this phase the stakeholder engagement structure and process, and the river basin modelling framework were also endorsed.

\subsubsection{Problem Analysis, Model Construction and Validation}

Information about system uncertainties and the dispute context was obtained through a set of individual consultation meetings. Two qualitative, concept models using system dynamics were constructed and validated jointly with stakeholders from Circle A to schematize systematic interactions and cause-effect relations between problems. The first model illustrated present water-related challenges. It showed cause-effect relationships regarding water withdrawal and water supply for agriculture and public water supply. The second model contained anticipated problems for the future horizon (2034). Outputs from the system dynamics model were used for constructing the schematization of the Pemali Comal water balance model using RIBASIM. Following this, data collection and model verification was performed by the modelling team in collaboration with stakeholders from Circle A.

\subsubsection{Model Validation and Formulation of Measures}

Due to persistent conflicts between water users in regards to the water withdrawals, uses, as well as cultural and hierarchical aspects (e.g. verbal dominance and freedom) (Akkermans and Vennix 1997) of the Indonesian policy and institutional setup, mediated modelling was applied during the model use phase. This commenced with the selection of the four scenario conditions (Section 2.3.3) with Circle A stakeholders followed by an interactive process of converting water resources issues into solutions using system dynamics. The RIBASIM model was run to quantify the cause-effect relations defined during the problem analysis phase. The complete concept system dynamics models used for problem analysis were transformed into incomplete models to determine suitable solutions to each specific problem. A total of 40 different measures were identified. They comprised infrastructural and soft measures, legal and institutional arrangements. These were then combined and evaluated based on the various scenario 
conditions using the RIBASIM model. After the prioritization of measures based on the outputs from the impact assessment, stakeholders and the modelling team selected the preferred strategy and incorporated it into the master plan. The master plan was then finalized and approved by the decision makers.

\subsection{Evaluation Process}

A comparative analysis was used to evaluate the impacts of using collaborative modelling for river basin planning (applied in the Eastern region) versus traditional water resources planning approaches (Western region). The collaborative modelling area comprised Pemalang, Pekalongan and Batang districts, and Pekalongan city. Similarly, Tegal and Brebes districts and Tegal city composed the conventional area (Fig. 1). Three mechanisms were used for data gathering: (i) project documents, (ii) semi-structured interviews with decision makers and local stakeholders, and (iii) semi-structured questionnaires with decision makers, local stakeholders, and the modelling and organizing team. The semi-structured interviews were designed following the Protocol of Canberra (Jones et al. 2009). The outcomes served for adapting the collaborative modelling approach to the local context and conditions. Semi-structured questionnaires were used for evaluating the progress and experiences from participants during the modelling and planning processes. In particular, two semi-structured questionnaires (i.e. preevaluation and post-evaluation forms) were distributed to stakeholders from Circles A and B. Both forms were designed using some of the contingencies for Group Model Building interventions (Akkermans and Vennix 1997). In the collaborative modelling area, an additional evaluation of the collaborative modelling approach and outcomes was also carried out (Fig. 4). The questionnaires are available in Annex A.

\section{Results and Discussion}

In this section, we present the results and stress practical lessons learnt from the collaborative modelling and traditional planning processes used for the preparation of the integrated river basin master plan for Pemali Comal River Basin Territory. Overall, the results of the three evaluation mechanisms suggest that the preparation of the master plan was effective, and it served to support informed and inclusive planning and decision making. Stakeholders and decision makers of the collaborative modelling area evaluated the general process and outcomes in a positive way (Fig. 4). Collaborative modelling has proved to be effective for structuring unstructured problems and the process has resulted in satisfactory outcomes.

\subsection{Integrated Approach}

An integrated river basin master plan needs to tackle the water-related issues in the basin in an integrated manner to secure water for all. The integrated approach is also conceived as a facilitating instrument to enhance group learning (Sterman 2001; Vennix 1996) and thus enhance cooperation among stakeholders (Bouwen and Taillieu 2004; Pahl-Wostl et al. 2007). The results of the comparative analysis corroborate these findings (Fig. 4). The collaborative modelling approach helped stakeholders gain an improved insight into the inter-linkages between issues. The results of the post-evaluation form in both areas show that 


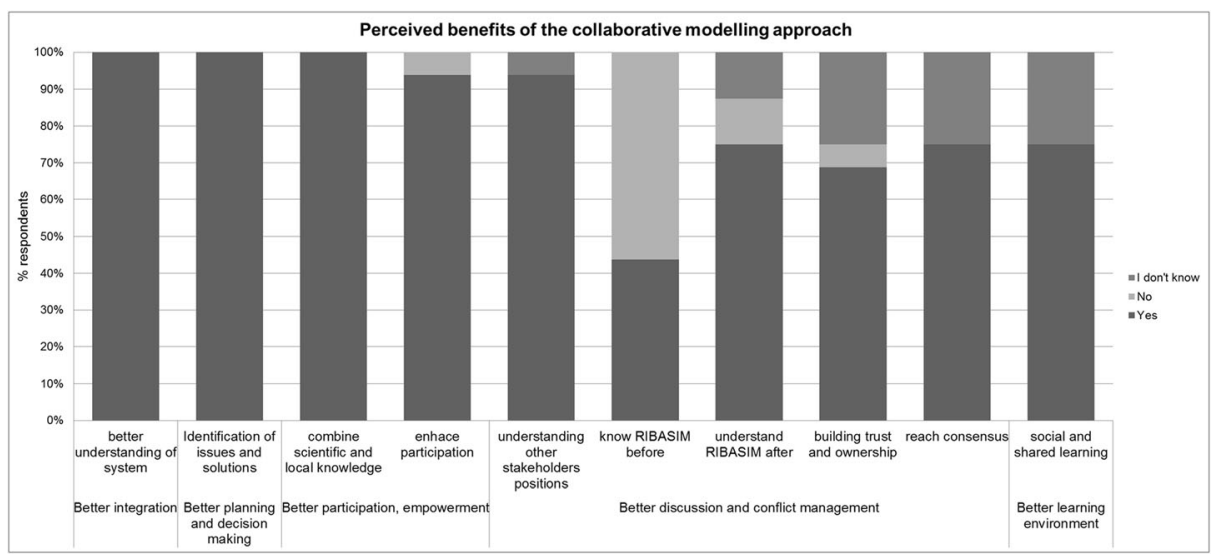

Fig. 4 Perceived benefits of the collaborative modelling approach

more than $92 \%$ of respondents are aware of the inter-connections between problems. However, when asked to explain some of the (cause-effect) relations, stakeholders from the conventional area had difficulty in describing these. Less that $18 \%$ could actually describe more than two inter-connections. In the collaborative modelling area, stakeholders (even those stakeholders with less technical background) could explain not only the connections between the majorities of problems but also explain the problems faced by other stakeholders. Stakeholders and decision makers corroborated that the joint identification and analysis of future problems using system dynamics helped to create awareness of future collective problems.

\subsection{Shared Learning: Better Understanding of the System and Evidence-Based Solutions}

Engaging stakeholders in model development and technical analysis fostered shared learning (Kirono et al. 2014; Langsdale et al. 2013; Voinov and Bousquet 2010). 70\% of the stakeholders and all the modelling team agreed that the collaborative modelling approach contributed towards shared learning. It helped decision makers and stakeholders having a good understanding of the functioning of the system and the impacts of possible interventions. Risks and costs could then be minimized. Collaborative modelling created a better learning environment for technicians to learn about the different systems by recognising the local knowledge and experience from the decision makers and stakeholders. Moreover, the joint and iterative construction of the RIBASIM model served to create awareness and consensus regarding the functioning of the different systems, water availability in the basin, water users, and present and future water-related problems. Moreover, construction a simple model and then improve it over time with input from stakeholders and experts (Langsdale et al. 2013) helped the process of getting familiar with system dynamics and RIBASIM.

Furthermore, collaborative modelling helps developing the technical capacity of stakeholders. Only 43,7\% of the stakeholders had heard about RIBASIM before commencing the project (Fig. 4). Further, none of them were familiar with the application. This result is surprising as RIBASIM had been used for the preparation of the strategic integrated river basin master plan in Pemali Comal, prior to this project. This might imply that a pure 
traditional planning approach was used for its preparation. Most stakeholders had however a better understanding of the functioning of system dynamics and RIBASIM model thanks to the use of collaborative modelling. They felt confident to be able, with some technical support, to develop such models and use them for planning purposes.

The impacts of using collaborative modelling or a traditional planning approach are also reflected in the formulation of measures by decision makers and stakeholders. In line with the major problems identified, structural measures were most prominent in both regions. In the East, O\&M (40\%), the use of Decision Support Systems (33,3\%), regulations and licensing (40\%) and awareness raising (13,3\%) were most valued. By contrast, conservation and land use measures $(41,7 \%)$, enhance cooperation $(41,7 \%)$ and better water resources management $(33,3 \%)$ were the most demanded measures in the West, where traditional methods were applied. This demonstrates that in the conventional area, stakeholders could perceive that the traditional planning approach did not enhance cooperation among stakeholders, so the disputes between stakeholders remained. Moreover, improving water resources management is a very generic solution. One could argue that decision makers and stakeholders did not have a good understanding of the physical, socio-economic and institutional system to find more detailed solutions. By contrast, in the collaborative modelling area, enhancing cooperation is not perceived as a major issue and the proposed solutions concerning the improvement of water resources management are much more concrete. Stakeholders and decision makers perceived more the benefits of soft measures and institutional mechanisms, rather than just grey infrastructure.

\subsection{Enhanced use of Participatory and Modelling Tools}

Collaborative modelling enhances the use of participatory, modelling and communication tools for inclusive and informed decision making. 93,3\% of respondents in both areas considered the use of planning support tools as important for better planning and decision making processes (Geurts and Mayer 1996). Group discussions is the most demanded participatory technique, with $66,7 \%$ in the collaborative modelling area and 58,3\% in the conventional area. The need of local knowledge from other stakeholders through group discussions and public consultation meetings was perceived as significantly important (46,7\%). Not surprisingly, the use of Decision Support Systems and modelling tools was requested much more in the collaborative modelling area $(60 \%)$ versus the conventional area $(25 \%)$. Stakeholders in the collaborative modelling area provided also detailed information on the type of technical studies required (e.g. water quality, coastal zone management), scenarios and river basin simulations. These technical studies were not only requested by stakeholders with technical and non-technical backgrounds (e.g. water users associations). Both perceived the advantages of using computer-based models for obtaining a better understanding the system, the water-related issues and testing of possible measures (Kumar et al.; Loucks and da Costa 2013; Loucks et al. 2005).

\subsection{More Efficient Modelling Process}

Collaborative modelling accelerates data collection, model construction and validation. Consequently the construction of the model is carried out much faster than following a traditional modelling approach. The engagement of stakeholders in the early modelling 
phases not only boosted shared learning but it also facilitated data collection. Stakeholders gained a comprehensive understanding of the data required (quantity and quality) for the construction of the models. This resulted in data collection not becoming a "bottle neck" for the project. Gaining time in data collection implied more available time for model validation. This iterative modelling process concluded with a widely accepted version of the Pemali Comal water balance and allocation model.

\subsection{Tackling Uncertainty to Build Trust and Ownership}

Collaborative modelling helped in enhancing trust in the models, gaining acceptance for the model results and this built ownership of the models and tools, as well as for the measures proposed and the integrated river basin master plan for Pemali Comal. Uncertainty related to data accuracy and completeness was one of the key factors affecting trust (Voinov et al. 2016). Although the functioning of the model was explained in several occasions, for some stakeholders it was not sufficient to obtain a good understanding of the model. For others, the collaborative modelling approach allowed them to spend time comprehensively discussing the model and its results. The iterative process helped them building ownership. Building trust and ownership was thus directly related to the time spent in developing knowledge and learning.

\subsection{Customization and use of Free-Available Modelling Tools is Critical}

A best practice identified by Langsdale et al. (2013) is to select software that is easy to learn and can be made available to all. The use of system dynamics for problem identification and measures formulation supported this practice; however, we encountered difficulties in customizing RIBASIM due to its "rigid" user-interface. RIBASIM was developed as a decision making tool for technicians. Its configuration is not sufficiently adequate for engaging all stakeholder groups in its construction and use. Respondents considered that making RIBASIM more user-friendly considering the needs, skills and backgrounds of stakeholders and making it free-available would both increase and enhance its use in decision making processes.

\subsection{Social Learning: Better Participation and Cooperation}

The majority of stakeholders (70\%) corroborated that collaborative modelling contributed towards social learning (Hurlbert and Gupta 2015; Mostert et al. 2007; Pahl-Wostl et al. 2007; Standa-Gunda et al. 2003; Voinov and Bousquet 2010) and had a significant effect in terms of consensus building. The comparison between the mental models and the quantitative model (i.e. RIBASIM) became a tipping point in creating a cooperative environment, as the information provided by the model was considered as being neutral during the discussions (Gaddis et al. 2010). Collaborative modelling facilitated that stakeholders and decision makers could learn from the concerns, needs and interests of other stakeholders. They could finally visualize and understand the problems faced by other stakeholder groups in regards to water withdrawal and supply. The process helped reaching the required level of consensus and trust for addressing the collective problems for the present and future situations and finding collective, sustainable solutions (Smajgl 2010). 


\subsection{Acceptance Requires of an Inclusive Well-Structured Stakeholder Engagement Process}

Early and continuous engagement of stakeholders is of key importance in collaborative modelling (Korfmacher 2001; Voinov and Gaddis 2008). The selection of appropriate stakeholder group representatives to create an appropriate working group is often considered as trivial; however this study has demonstrated its relevance. Local NGOs participated in the study; however their involvement was restricted to Circle C. Not incorporating and considering sufficiently all forms of stakeholder knowledge and their concerns, especially from NGOs, resulted in the Indonesian Constitutional Court revoking the 2004 water resources law in 2015 due to disagreements arisen mainly by local NGOs on the maintenance of clean water access. The integrated river basin master plan can thus not be endorsed and implemented; instead it needs to be prepared again under a new legislation is adopted.

\section{Conclusions}

This article has demonstrated the benefits of using a collaborative modelling approach for the preparation of the integrated river basin master plan for Pemali Comal in comparison with traditional planning methodologies. Results from the study demonstrate the importance of the adaptive structure of a collaborative modelling approach. In this case, the heterogeneity of stakeholder groups in terms of hierarchical diversity, verbal dominance, freedom, organizational practices, background, culture and existing conflicts required the adaptation of the approach from Group Model Building for model construction to mediated modelling for model use. The approach also shows the benefits of using system dynamics in combination with RIBASIM. Both analytical models were useful for characterizing and analysing the socio-physical system and their inter-relations. The use of the water security framework helped to structure and guide the formulation of potential measures, and led to the integrated planning approach required for sustainable IWRM. However, further analysis is necessary to transform the outputs from the IWRM planning process into specific inputs for evaluating water security in the region.

This study demonstrates that the collaborative modelling approach helped better planning and decision making. Collaborative modelling supported the process of problem identification and measures formulation. It ensured fruitful stakeholder participation during the overall planning process, particularly during the modelling phases. Collaborative learning and the neutral atmosphere created by the use of modelling tools helped change the mental models of stakeholders regarding the functioning of the water resources system and the problems faced by other stakeholders. This was critical for transforming the initial disputes among competing water users into a more cooperative environment. All these factors enhanced stakeholder trust in the model and its results, and strengthened the sense of ownership of the integrated river basin master plan for Pemali Comal River Basin Territory. This case demonstrates the benefits of collaborative modelling for enhancing informed decision making, evidence-based solutions and ensuring inclusive planning for sustainable water resources development.

Acknowledgements The funding and knowledge support for this research provided by Deltares and WISMP2BWRMP project from the World Bank is thankfully acknowledged. We appreciate the support from Aart van Nes, Jos Dijkman, Daniel Tollenaar and Aris Setiawan in Indonesia and the guidance and contributions from Karen Meijer and Olivier Tuyishimire in the Netherlands. We are very thankful for the support of Andrew Warren as reviewer. 
Open Access This article is distributed under the terms of the Creative Commons Attribution 4.0 International License (http://creativecommons.org/licenses/by/4.0/), which permits unrestricted use, distribution, and reproduction in any medium, provided you give appropriate credit to the original author(s) and the source, provide a link to the Creative Commons license, and indicate if changes were made.

\section{References}

ADB (2013) Asian water development outlook 2013. Measuring water security in Asia and the Pacific. Asian Development Bank, Mandaluyong City

ADB (2015) Making it happen: Technology, finance and statistics for sustainable development in Asia and the Pacific. Asia-Pacific Regional MDG Report 2014/15. Asian Development Bank (ADB), United Nations Economic and Social Commission for Asia and the Pacific (UN ESCAP) and the United Nations Development Programme (UNDP), Bangkok

ADB (2016) River Basin management planning in Indonesia: policy and practice. Asian Development Bank, Mandaluyong City

Akkermans HA, Vennix JA (1997) Clients' opinions on group model-building: an exploratory study. Syst Dyn Rev 13(1):3-31

Arnstein SR (1969) A ladder of citizen participation. J Am Inst Plann 35(4):216-224

BAPPENAS (2008) Rencana Pembangunan Jangka Panjang (RPJP) Nasional 2005-2015

Basco-Carrera L, Warren A, Van Beek E, Jonoski A, Giardino A (2016) Collaborative modelling or participatory modelling? A Framework for Water Resources Management. (In review Environmental Modelling \& Software - copy on file with author)

Biswas AK (2008) Integrated water resources management: is it working? Water Resour Dev 24(1):5-22

Bourget L (ed) (2011) Converging waters: integrating collaborative modeling with participatory processes to make water resources decisions. Institute for Water Resources, U.S. Army Corps of Engineers

Bousset J-P, Macombe C, Taverne M (2005) Participatory methods, guidelines and good practice guidance to be applied throughout the project to enhance problem definition, co-learning, synthesis and dissemination. SEAMLESS

Bouwen R, Taillieu T (2004) Multi-party collaboration as social learning for interdependence: developing relational knowing for sustainable natural resource management. J Community Appl Soc Psychol 14(3):137-153

Bruns B (2003) Water tenure reform: developing an extended ladder of participation. Politics of the Commons: Articulating Development and Strengthening Local Practices, Chiang Mai

Cardwell H, Langsdale S, Stephenson K (2008) The shared vision planning primer: how to incorporate computer aided dispute resolution in water resources planning. Institute for Water Resources, Alexandria, IWR Report

Cook C, Bakker K (2012) Water security: debating an emerging paradigm. Glob Environ Chang 22(1):94-102

Deltares (2012) Water security atlas. Atlas Ketahanan Air. Java Water Resources Strategic Study. Deltares, DHV, MLD, Wiratman \& Associates, Indonesia

Gaddis EJB, Falk HH, Ginger C, Voinov A (2010) Effectiveness of a participatory modeling effort to identify and advance community water resource goals in St. Albans, Vermont. Environ Model Softw 25(11):1428-1438

Geurts J, Mayer I (1996) Methods for participatory policy analysis: towards a conceptual model for research and development. WORC report 9612

Graaf H, Hoppe R (1996) Beleid en politiek. Een inleiding tot de beleidswetenschap en de beleidskunde

Grey D, Sadoff CW (2007) Sink or swim? Water security for growth and development. Water Policy 9(6):545-571

Grimble R, Chan MK (1995) Stakeholder analysis for natural resource management in developing countries, Natural resources forum Wiley Online Library pp 113-124

GWP (2000) Integrated water resources management. TAC Background Papers. Global Water Partnership Technical Advisory Committee 4

GWP (2012) Increasing water security - a development imperative, TAC Background Papers. Global Water Partnership (GWP)

Henriksen HJ, Refsgaard JC, Højberg AL, Ferrand N, Gijsbers P, Scholten H (2009) Harmonised principles for public participation in quality assurance of integrated water resources modelling. Water Resour Manag 23(12):2539-2554

Hommes S (2008) Conquering complexity: dealing with uncertainty and ambiguity in water management. University of Twente, The Netherlands

Hurlbert M, Gupta J (2015) The split ladder of participation: a diagnostic, strategic, and evaluation tool to assess when participation is necessary. Environ Sci Pol 50:100-113

Jeuken A, Haasnoot M, Reeder T, Ward P (2015) Lessons learnt from adaptation planning in four deltas and coastal cities. Journal of Water and Climate Change 6(4):711-728

Jones NA, Perez P, Measham TG, Kelly GJ, d'Aquino P, Daniell KA, Dray A, Ferrand N (2009) Evaluating participatory modeling: developing a framework for cross-case analysis. Environ Manag 44(6):1180-1195 
Kirono DG, Larson S, Tjandraatmadja G, Leitch A, Neumann L, Maheepala S, Barkey R, Achmad A, Selintung M (2014) Adapting to climate change through urban water management: a participatory case study in Indonesia. Reg Environ Chang 14(1):355-367

Korfmacher KS (2001) The politics of participation in watershed modeling. Environ Manag 27(2):161-176

Kumar S, Godrej AN, Grizzard TJ (2015) A web-based environmental decision support system for legacy models. J Hydroinf 17(6):874-890

Langsdale S, Beall A, Bourget E, Hagen E, Kudlas S, Palmer R, Tate D, Werick W (2013) Collaborative modeling for decision support in water resources: principles and best practices. JAWRA Journal of the American Water Resources Association 49(3):629-638

Loucks DP, da Costa JR (2013) Decision support systems: water resources planning. Springer Science \& Business Media

Loucks DP, Van Beek E, Stedinger JR, Dijkman JP, Villars MT (2005) Water resources systems planning and management: an introduction to methods, models and applications. UNESCO, Paris

Medema W, McIntosh BS, Jeffrey PJ (2008) From premise to practice: a critical assessment of integrated water resources management and adaptive management approaches in the water sector. Ecol Soc 13(2):29

Mintzberg H (1978) Beyond implementation: an analysis of the resistance to policy analysis. École des hautes études commerciales

Mostert E (2003) The challenge of public participation. Water Policy 5(2):179-197

Mostert E, Pahl-Wostl C, Rees Y, Searle B, Tàbara D, Tippett J (2007) Social learning in European river-basin management: barriers and fostering mechanisms from 10 river basins. Ecol Soc 12(1):2007

Muller M, Lenton R (2009) Integrated water resources Management in Practice. Earthscan, London

Pahl-Wostl C, Craps M, Dewulf A, Mostert E, Tabara D, Taillieu T (2007) Social learning and water resources management. Ecol Soc 12(2):2007

Sadoff CW, Grey D (2005) Cooperation on international rivers: a continuum for securing and sharing benefits. Water Int 30(4):420-427

Serrat-Capdevila A, Valdes JB, Gupta HV (2011) Decision support systems in water resources planning and management: stakeholder participation and the sustainable path to science-based decision making. Efficient decision support systems - practice and challenges from current to future. India, InTech

Smajgl A (2010) Challenging beliefs through multi-level participatory modelling in Indonesia. Environ Model Softw 25(11):1470-1476

Speed R, Li Y, Le Quesne T, Pegram G, Zhiwei Z (2013) Basin water allocation planning. Principles, procedures and approaches for basin allocation planning. UNESCO, Paris

Standa-Gunda W, Mutimukuru T, Nyirenda R, Prabhu R, Haggith M, Vanclay JK (2003) Participatory modelling to enhance social learning, collective action and mobilization among users of the Mafungautsi Forest, Zimbabwe. Small-Scale Forestry 2(2):313-326

Sterman JD (2001) System dynamics modeling: tools for learning in a complex world. Calif Manag Rev 43(4):8-25

Sukardi S, Warsito B, Kisworo H, Sukiyoto (2013) River Management in Indonesia. Directorate general of water resources, Yayasan Air Adhi Eka. International Cooperation Agency, Japan

United Nations (2016) Sustainable Delvelopment Goals www.un.org/sustainabledevelopment/

UN-Water (2006) Coping with water scarcity-a strategic issue and priority for system-wide action. UN-Water Thematic Initiatives

UN-Water (2013) Water security and the global water agenda: a UN-water analytical brief. UN University, Hamilton

Van Beek E, Arriens WL (2014) Water security: putting the concept into practice. GWP TEC Background Paper(20)

Van den Belt M (2004) Mediated modeling: a system dynamics approach to environmental consensus building. Island press, Washington

van der Krogt WNM, Boccalon A (2013) River Basin simulation model RIBASIM version 7.00. User manual. Deltares report 1000408-002

Vennix JA (1996) Group model building: facilitating team learning using system dynamics. Wiley, Chichester

Vennix JA (1999) Group model-building: tackling messy problems. Syst Dyn Rev 15(4):379-401

Videira N, Antunes P, Santos R (2017) Engaging stakeholders in environmental and sustainability decisions with participatory system dynamics modeling, environmental modeling with stakeholders. Springer, pp 241-265

Voinov A, Bousquet F (2010) Modelling with stakeholders. Environ Model Softw 25(11):1268-1281

Voinov A, Gaddis EJB (2008) Lessons for successful participatory watershed modeling: a perspective from modeling practitioners. Ecol Model 216(2):197-207

Voinov A, Kolagani N, McCall MK, Glynn PD, Kragt ME, Ostermann FO, Pierce SA, Ramu P (2016) Modelling with stakeholders-next generation. Environ Model Softw 77:196-220

Wahyudi SI, Ni'am MF, Le Bras G (2012) Problems, causes and handling analysis of tidal flood, erosion and sedimentation in northern coast of central Java: review and recommendation. International Journal of Civil \& Environmental Enginering 12(04):65-69

WEF Water Initiative (2010) Water security: the water-food-energy-climate nexus. World Economic Forum (WEF). Island Press, Washington 